\title{
A Survival Story from the Thai-Burmese Border: The Struggle for Education in the Burmese Community in Thailand
}

\author{
Mary Purkey
}

\begin{abstract}
The Burmese refugee/migrant community on the ThaiBurmese border figures prominently among "refugee diasporas" in the world today. This article describes efforts of Burmese people within this community to provide basic education to their youth in extra-legal migrant schools in the midst of the unwelcoming environment created by the Thai government's refugee policy. It argues that this community needs greater support than it is currently receiving in order to achieve recognition and security given the impossibility of safe and voluntary repatriation to Myanmar in the foreseeable future. The article closes with a number of specific proposals for facilitating the delivery of education to Burmese "migrant" youth in the Burmese community in Thailand through intervention by both state and nonstate actors.
\end{abstract}

\section{Résumé}

La communauté birmane de réfugiés/migrants à la frontière birmano-thaïlandaise est actuellement l'une des composantes importantes des "diasporas de réfugiés" dans le monde. L'article décrit les efforts du peuple birman de cette communauté, visant à offrir une éducation de base aux jeunes dans des écoles de migrants extrajudiciaires, dans le contexte d'un environnement importun créé par la politique en matière de réfugiés du gouvernement thaïlandais. Il affirme que cette communauté a besoin d'un plus grand soutien que celui qu'elle reçoit actuellement pour atteindre la reconnaissance et la sécurité, étant donné l'impossibilité d'un rapatriement sécuritaire et spontané au Myanmar dans un futur rapproché.
L'article offre en conclusion bon nombre de propositions spécifiques en vue de faciliter la dispense de l'éducation à la jeunesse "migrante" de la communauté birmane de Thaïlande, grâce à l'apport d'intervenants des sphères publiques et privées.

$\mathrm{E}$ verywhere in the world, people are on the move, most not because they want to be. They have picked up what few belongings they could carry and set off, usually because the places they nostalgically call home have become intolerable sites of exploitation or violence. Or worse yet, they may have disappeared altogether as armed gangs, paramilitaries, or state armies sweep through their villages burning their houses, killing their animals, destroying their fields, making life insupportable. Such is the case in much of eastern Myanmar, and there, as in other places, the fleeing populace takes with it a whole generation of children as they cross the border into Thailand in search of security. Sometimes, when these people cannot make it themselves, they send their children on alone. In either case, once across, the children face not only the same hardships as their parents but in addition the deprivation of that so-fundamental right that the United Nations, virtually every state in the world, and people far and wide hold dear: the right to an education.

Among those concerned about the displacement of people by conflict, the town of Mae Sot, Thailand, has become well known as an enclave of Burmese refugees and economic migrants. The distinction between these two groups is murky at best since the persecution that people face in Myanmar is both political and economic. The failure of the Thai government to ratify the United Nations Convention on Refugees means that the illegal migrant community 
bears all the burdens of refugees without any of the benefits (such as the education provided in refugee camps) or even the legitimacy that comes with recognition as refugees. The abuses of rights and humanitarian problems displaced Burmese people face trying to survive along both sides of the Thai-Burmese border have been well documented by the many NGOs that work there, by Human Rights Watch and by the United Nations. So have the causes of their displacement. See, for example, the "Statement on 'Abuse of Migrant Workers in Thailand" published by the Asian Legal Resource Centre for presentation to the United Nations Commission on Human Rights in April 2004. ${ }^{1}$ In addition, a number of reports such as "Small Dreams beyond Reach: The Lives of Migrant Children and Youth along the Borders of China, Myanmar and Thailand" by Therese M. Caouette have documented reasons for lack of education among migrant children on the border along with other problems stemming from the existence of child labour, trafficking, and HIV/AIDS. ${ }^{2}$ What have received somewhat less attention are the extraordinary efforts of both documented and undocumented migrant Burmese people to continue their children's education in the absence of financial support, infrastructure, and legal status in Thailand.

Traveling to Mae Sot in 2003 and in January of this year, I have had the opportunity to witness some of these efforts. I have visited seven of the thirty or so migrant schools in and around Mae Sot, all started by very caring and determined Burmese expatriates and all functioning only with considerable difficulty. The problems are myriad: In two cases, the schools I visited also operate as makeshift orphanages for children who have crossed, or been sent across, the border unaccompanied or who have lost families because of the ethnic conflict in Myanmar. The identity of these school-orphanages has to be hidden from public view because of their lack of official legal status. The accommodation provided for live-in children is rustic at best. Sanitation is difficult to maintain, food is limited, lighting is minimal, learning spaces double as sleeping quarters, and mosquito netting is shared by whole groups.

For children who live with families in Mae Sot and travel to school, there is constant worry about security. Parents who themselves risk deportation when they are out and about can hardly send their children off to school alone. Transport to school is thus a huge but unavoidable expense for those who want their children in school. Children disappear from the schools because their mothers' work permits have expired or because they never had permits and have been picked up and deported back across the border, or if their parents have been deemed "bona fide refugees" under the government of Thailand's peculiar definition of refugees as persons fleeing armed conflict, they may have been directed back to a refugee camp in the inhospitable jungle.

Facilities, teaching personnel, and materials also present problems. The stairs on one school building, a converted house, are rotting. Another school with reasonable capacity for perhaps one hundred children has 230, 170 of whom are boarding, i.e., unaccompanied youth who have slipped over the border. There are few if any books and no money for photocopying, no crayons, no real chalkboard. Several languages compete in the same learning space, and there is rarely anyone qualified to teach Thai, the one language that would enable children to seek education in Thai schools. The curriculum is, at best, an effort to replicate the antiquated and rigid curriculum of Myanmar's on-again, offagain educational system. The overworked teachers are full of good humour and care, but some lack basic knowledge in the subjects they must teach. All have worries of their own regarding the need for expensive work permits and fears of deportation. In the midst of such problems, children gather to sing "Head, Shoulders, Knees and Toes" for the visitor from Canada. When asked what they would like most for their school, they respond, "sky-blue shirts" for their football team. Their games and dreams are the same as those of children everywhere.

Older children in these schools face the reality that when they reach the age of fifteen, the Thai government will no longer view them as children, with at least a theoretical right to education. All but the very brightest and luckiest will face an uncertain future with few choices except to become illegal workers like their parents or to return to Myanmar to face a politically and economically repressive situation there. A very lucky, very few might get the attention of some NGO, follow a western, distance education program, pass a Test of English as a Foreign Language (TOEFL), win a scholarship abroad, and join the brain drain from Southeast Asia. None of these alternatives is acceptable.

The research done during my first journey to Mae Sot contributed to development of a modest pilot project based in the Eastern Townships of Quebec to extend assistance to at least some of the Burmese-run schools for migrant children. It is called the Eastern Townships-Mae Sot Education Project. The conception was simple: raise funds to send students from the two educational institutions in our community (Champlain Regional College and Bishop's University) to provide volunteer assistance in schools for migrant children in Mae Sot. In the process, the project would educate our own community regarding the needs of displaced people, create a network of support for the Burmese migrant community along the Thai border, and build leadership skills of youth in two communities on opposite sides of the world. After working for one and one-half years to 
raise money in our own community and to select and prepare young volunteers for this project, it has begun to bear fruit. During the last year, five young Canadians have volunteered for six-month periods at five migrant schools created and run by Burmese people of various ethnicities in Mae Sot. Their primary role has been ostensibly to teach English as a second language; however, knowing that the children on the border-and their schools-have needs more essential than English (though that does definitely have uses), our volunteers' real challenge has been to spot a wide variety of specific needs and help us meet them or find someone who can.

The e-mails coming back to Quebec from the volunteers paint a picture of buoyant good spirits and determination among desperate conditions. They tell stories: One boy, orphaned since the age of three because his father was cruelly killed by the military junta (the SPDC) in Myanmar and his mother died in childbirth, thrives because of the care of a school headmaster and his wife. He wants "to become an educated person" and help his school. A sixteenyear-old girl, born in the jungle along the border and raised by her parent-revolutionaries, has "a deep wish to help the helpless.” Another, a five-year-old, appeared at the school after her mother, a single parent, died. She too wants to help "helpless students" like herself. Then there are the stories that form the discomfiting backdrop for whatever "normalcy" exists within the school walls. A child's uncle back in Insein Prison in Myanmar dies mysteriously. Two young girls in a nearby refugee camp commit suicide and another goes blind trying. Across the border, the KNU, a Karen ethnic guerrilla army, recruits ex-child soldiers who have escaped from the Myanmar military forces.

Teachers too have their stories. Some, like the sixty-fiveyear-old headmaster of one of the oldest of the migrant schools in Mae Sot, are well educated and have experienced imprisonment and torture in Myanmar because of their involvement in the democracy movement. They are courageous and persistent people committed to the education of these children, prepared to live and work under harsh conditions for little or no remuneration with constant insecurity. Others are young and have fled Myanmar because of their involvement in opposition political activities or protests against the restrictive education policies of the State Peace and Development Council [Myanmar's ruling military junta, more commonly known as the SPDC]. They have stories of flight and hiding. One says philosophically:

I suppose that the lives of the teachers here are like gardeners of human plants. We work to cultivate the minds of our dear children, who are the future of our beautiful world.... The work we do does not aim to create stepping stones towards success, but to form strong bridge which hopefully one day our children may walk over into their own country. Helping the children is the right way to heal our country and then the world. ${ }^{3}$

Being a young western volunteer in this refugee/migrant community involves both exposure to a wealth of rich and warm intercultural experiences and a growing consciousness of the quantity and direness of the children's needs and of the absence of clear solutions. One of our volunteers wrote in a recent e-mail:

It is daunting to be in an environment where adults must struggle to provide their youth with a basic education.... These teachers provide hope to children who have lost their parents and are too young to understand the political situation of their nation.... The students are truly wonderful. They are eager to learn despite their lack of learning materials, but the school is desperate for financial support. It relies on private donors, and I wonder how long it can continue to provide for its students.

The key issue? There is simply no body in the world that has shown itself willing to take responsibility, financially or otherwise, for the education of Burmese migrant children in Thailand as a group. Although some NGOs, and indirectly through them some governments, do provide assistance, most, understandably cautious to protect their own legal status in Thailand, shy away from overt support for migrant schools. The schools are, after all, "extra-legal" at best. Unofficially, discreetly, some schools do also receive moral support from the Thai educational and religious communities which may be aware that having these children in school serves everyone's interests in the end. The resourcefulness of the Burmese people themselves in digging into their own not-very-deep pockets and in pursuing anyone who will pay attention-some churches and underfunded NGOs, Burmese trade unions, and religious organizations-is definitely cause for admiration. Most do manage to find enough money to struggle along month by month on budgets of about $\$ 7,000$ to $\$ 15,000$ USD per year depending on enrolment. However, the search for funding is both unending and demoralizing. No people, even those displaced and lacking legal status or recognition, should have to plead-or grovel-before strangers so that their children can claim the internationally lauded right to basic education.

What is needed? It is not sufficient that well-meaning volunteers from many countries try to put together a patchwork of meagre support for these migrant schools. Nor is it sufficient that in the last few years the right of Burmese children in Thailand to education has been recognized at a theoretical level by the Thai government, because that rec- 
ognition has not translated into material support. To be fair, the expectation that the Thai government can and should bear the burden of developing an educational system for the Burmese migrant community may be both unrealistic and unfair. As long as the SPDC continues to deny legitimate democratic opposition and to pursue cruel economic policies and practices, the states of the world that make up the United Nations and that have taken upon themselves the role of defender of children's rights (i.e., the ratifiers of the UN Covenant on the Rights of the Child) need to provide material support so that these children can claim their right to education where they are, across the border in Thailand. They also need to urge the Thai government to loosen its recently heightened restrictions on migrant workers and refugees and to stop deporting them. Finally, they need to use their considerable economic power to influence the Thai government, along with ASEAN, to stop treating the SPDC as just another trading partner and to take concrete measures to encourage development of democratic government in Myanmar so that Burmese people in Thailand and elsewhere can go home.

Granting the unlikelihood of such actions in the near future and the immediacy of the children's needs, a number of other practical and specific measures to improve the delivery of education to Burmese migrant children could and should be taken with outside assistance from a variety of parties.

\section{Basic materials}

The greatest immediate challenge that migrant schools face is very simply the almost complete lack of instructional materials, especially books, for providing a rounded general education, whether in Burmese, Thai, or English. Basic supplies for these schools must be provided on a better than ad hoc basis. A number of bodies exist in Thailand through which funding and materials to schools could be channeled. The Thai government must allow UN agencies to assume responsibility to insure that it is done. At the same time, however, especially if this responsibility is seen to rest with the UNHCR, recognizing that it has no budget and depends on the good will of donors, the onus is on those states that see themselves as defenders of children's right to education to provide the resources.

\section{Teacher training and curriculum development}

A curriculum appropriate to the children's needs, one that will help them make their way in the world outside Myanmar as well as within (in the event that democracy one day comes to their country), needs to be developed. Currently, a variety of programs imported from Australia, the United States, Canada, and other western countries are applied on an ad hoc basis. None of them addresses adequately the need of these children for instruction in the Thai language as well as in their own national and ethnic languages, essential keys to their educational advancement. Many of the Burmese educators in Thailand need more general education themselves. Few are capable of meeting the educational needs of older, more advanced students. All of them need assistance in developing a curriculum that suits their social context and educational objectives and that can be used widely and consistently. One very exciting initiative in this direction is a teacher training certificate program, Teacher Training for Burmese Teachers (TTBT), developed by Burmese educators Dr. Thein Lwin and Nan Lung in Chiang Mai. Using Reading and Writing for Critical Thinking (RWCT), a program initiated by the Open Society Institute (OSI) and the International Reading Association, it provides a threemonth, post-graduate teacher education course to teachers returning to Burma but also to those teachers working in the border regions who have received permission from the Thai government to attend. In the three years since it began, approximately seventy-five teachers have been able to benefit from this program. Dr. Lwin and Ms. Lung have also conducted RWCT intensive training and certification workshops in Mae Hong Son, Mae Sot, and some refugee camps for other educators who are not able to travel in Thailand. The program reflects a vision of education that embraces critical thinking, active learning, and development of educational policies appropriate to a democratic society. Currently, it is dependent on some individuals and charitable organizations for financing. It is the kind of effort that needs more committed support from institutions concerned about building a democratic society in Burma.

\section{Collaboration between schools leading to common standards}

As a corollary to the above, a system needs to be put in place that would help these schools to work together and to share information and resources more effectively and transparently and that would allow students to transfer from one school to another. The Burmese ethnic communities themselves must set aside some of their suspicions of each other in order to accomplish this goal. Some organizations, such as the Burmese Migrant Workers Education Committee, are working hard to promote collaboration. Guidance in developing school administrative structures that foster this collaboration would enhance the process. In addition, however, support is needed for some kind of international recognition for students who actually manage to complete secondary education. In her report "Small Dreams beyond Reach: The Lives of Migrant Children and Youth along the Borders of China, Myanmar and Thailand," Therese M. Caouette stated: 
Even though Thailand recently announced a policy to allow undocumented children to attend Thai schools, the policy is not consistently implemented. This study found few migrant children along the border in school. Those who did attend school were unable to receive certification of their studies due to their lack of documentation, which consequently limits their opportunities for further education. ${ }^{4}$

In sum, support and direct assistance by states and by institutions of higher learning worldwide for creation of the infrastructure needed for collaboration and for documentation and transfer of credits are needed.

\section{Support for post-secondary education in Thailand}

Those children nearing the age of sixteen, facing the prospect of deportation or illegal status, need to have places to go to continue their education. Through the Burma Fund of the Open Society Institute and organizations such as World University Service of Canada, some students manage to obtain scholarships and other forms of assistance to continue studies abroad. This alternative, available to only a lucky few, is positive yet problematic in that it accelerates the exit of the most talented Burmese youth from their region-where they might be in a position to influence development in their country. The Thai government is clearly happy to see them leave. However, conceivably, with outside financial support or other inducements, it might become more receptive to having Burmese students complete university education in Thailand. Ultimately, until good government comes to Myanmar, returning there for post-secondary education is not a realistic or safe option.

\section{Legal recognition}

As already noted, currently, migrant schools exist outside the Thai education system-illegally, or more accurately extra-legally, officially invisible. The legitimacy of the schools' existence must be recognized before the measures described above can be taken. In addition, however, until a process exists for providing displaced children themselves with legal identity documents, documenting their educational achievements and insuring an educational future for them will continue to be difficult. Thus perhaps more fundamentally, it is imperative that undocumented Burmese children receive legal documents attesting to their existence, something to which all humans are surely entitled.

The Human Rights Watch report "Out of Sight, Out of Mind: Thai Policy toward Burmese Refugees," published in February 2004, describes a host of larger problems that form the backdrop for those described in this paper. ${ }^{5}$ Among them are the disagreement regarding the basic definitions of displaced Burmese people's situations as refugees, asylum seekers, and/or economic migrants and the more basic need of all human beings for protection. Although the courageous and persistent efforts of Burmese educators in the migrant schools in Thailand-and the hardships they face-may be insignificant in view of these fundamental problems, for many children along the border, they define both the day-to-day reality of life in a diaspora community and the future. These schools represent a valiant initiative by displaced people who are in the eyes of the world press and most governments "out of sight, out of mind" to lift themselves up. In a world of sad stories of hopelessness and defeat, they are small but inspiring bright lights. They deserve recognition and support from the international community.

\section{Notes}

1. Asia Legal Resource Centre, "Statement on 'Abuse of Migrant Workers in Thailand' Received by Commission on Human Rights," news release, Geneva, 7 April 2004; <http://www. alrc.net/pr/mainfile.php/2004pr/61/>.

2. Therese M. Caouette, Small Dreams beyond Reach: The Lives of Migrant Children and Youth along the Borders of China, Myanmar and Thailand, Save the Children, United Kingdom, 2001; <http://www.savethechildren.org.uk/temp/scuk/cache/ cmsattach/412_smalldreams.pdf $>$.

3. Kyaw Moe, A House We Call Our School, information booklet on the Boarding School for Orphans and Helpless Youths (Mae Pa, Thailand: BMSOH, 2004).

4. Caouette, 84 .

5. Human Rights Watch, "Out of Sight, Out of Mind: Thai Policy toward Burmese Refugees" (Human Rights Watch, New York, Vol. 16, No. 2, February 2004); <http://www.hrw.org/reports/ 2004/ thailand0204/thailand0204.pdf $>$.

Mary Purkey coordinates International Studies and teaches Humanities at Champlain Regional College-Lennoxville in the Eastern Townships of Quebec and has also cocoordinated the Bishop's University-Champlain College Refugee-Student Sponsorship Committee for the last twelve years. In 2003, she and a group of committed citizens in Lennoxville started the Eastern Townships-Mae Sot Education Project, a small volunteer project to assist Burmese refugee/migrant children in Mae Sot, Thailand, and raise consciousness regarding their situation among Canadians. 